\title{
PERFORMANSI PERTUMBUHAN DAN REPRODUKSI UDANG WINDU ASAL TAMBAK YANG DIBERI KOMBINASI PAKAN YANG BERBEDA
}

\author{
Asda Laining, Usman, Muslimin, dan Neltje Nobertine Palinggi \\ Balai Penelitian dan Pengembangan Budidaya Air Payau \\ Jl. Makmur Dg. Sitakka No. 129, Maros 90512, Sulawesi Selatan \\ E-mail: asdalaining@yahoo.com
}

(Naskah diterima: 26 Desember 2012; Disetujui publikasi: 30 Desember 2013)

\begin{abstract}
ABSTRAK
Penelitian ini bertujuan untuk mendapatkan formulasi pakan induk udang windu serta feeding regime-nya untuk mendukung usaha domestikasi udang windu baik di tambak maupun dalam wadah terkontrol. Kegiatan diawali dengan pemeliharaan udang di tambak hingga bobot udang mencapai fase prematurasi atau bobot udang sekitar 60$70 \mathrm{~g}$. Pada tahap uji pakan fase prematurasi, perlakuan yang dicobakan adalah: 1) 100\% pakan induk komersil (100SP); 2) 40\% pakan segar dan 60\% pakan induk komersil bentuk semi-moist pelet (40FF60SP); dan 3) 40\% pakan segar dan 60\% pakan uji bentuk pelet kering (40FF60DP). Pakan segar yang diberikan adalah cumi-cumi dan cacing laut. Perlakuan yang dicobakan pada uji pakan fase maturasi adalah: 1) 100\% pakan segar (100FF); 2) 40\% pakan segar dan 60\% pakan induk komersil bentuk semi-moist pelet (40FF60SP); dan 3) 40\% pakan segar dan $60 \%$ pakan uji bentuk pelet kering (40FF60DP). Sintasan udang windu selama 100 hari pemeliharaan di tambak adalah $30 \%$, sementara pertambahan bobotnya sebesar $95 \%$. Selama 90 hari pemeliharaan di bak terkontrol, udang yang matang gonad secara alami pada uji pakan fase prematurasi ditemukan pada perlakuan 100SP dan 40FF60DP. Pada uji pakan fase maturasi betina yang matang gonad secara alami dan memijah ditemukan pada udang yang diberi pakan 40FF60DP dan 100FF. Kisaran dan rata-rata fekunditas telur (butir/induk/pemijahan) baik yang matang alami maupun setelah ablasi untuk masing-masing perlakuan adalah 60.000-260.000 (135.000) untuk 100SP; 30.000 (15.000) untuk 40FF60SP; dan 105.000-135.000 (120.000) untuk 40FF60DP. Kadar DHA, EPA, dan ARA dalam karkas induk yang diberi pakan 40FF60DP tertinggi dibandingkan dua pakan lainnya. Alkalinitas selama pemeliharaan berlangsung baik untuk uji pakan fase prematurasi maupun maturasi relatif rendah yaitu $<85 \mathrm{mg} / \mathrm{L}$. Berdasarkan perkembangan gonad secara alami pada fase prematurasi, udang windu yang diberi pakan 40FF60DP memberikan performansi yang lebih baik dan pada fase maturasi pun kombinasi pakan 40FF60DP memberikan performansi reproduksi yang relatif sama dengan 100FF dan lebih baik dibandingkan dengan 40FF60SP.
\end{abstract}

KATA KUNCl: maturasi, semi-moist pelet, matang gonad

ABSTRACT: Growth and reproductive performance of pond reared tiger shrimp fed different combinations of maturation diet. By: Asda Laining, Usman, Muslimin, and Neltje Nobertine Palinggi

This experiment was aimed to develope the diet formulation for maturation of tiger shrimp as well as its feeding regime to support domestication of tiger shrimp reared both in pond and indoor closed system. This experiment was started by culturing young shrimp in earthen pond until reaching pre-maturation stage or shrimp weight approximately around $60-70 \mathrm{~g}$. For feeding trial of pre-maturation stages, tested diets were three different combination diets namely 1) 100\% commercial semi-moist 
maturation pellet (100SP); 2) 40\% freshfeed combined with $60 \%$ commercial semimoist maturation pellet (4OFF6OSP); and 3) 40\% freshfeed combined with $60 \%$ inhouse dried maturation pellet (4OFF6ODP). Freshfeed used in the trials were squid and seaworm. Experimental diets used for maturation stages were 1) 100\% freshfeed (100FF); 2) $40 \%$ freshfeed combined with $60 \%$ commercial semi-moist maturation pelet (4OFF60SP); and 3) 40\% freshfeed combined and 60\% in-house dried maturation pellet (4OFF60DP). Survival rate of shrimp during 100 days culture in earthen pond was $30 \%$ and the average weight gain was $95 \%$. During 90 days culture in outdoor tank at prematuration stage, the naturally matured females were found in group fed $100 S P$ and 4OFF60DP. Moreover, during feeding trial of maturation stages, naturally matured females were first observed in groups fed 40FF60DP and later in 100FF. Ranges (averages) of eggs per spawning for both naturally mature and ablated mature were 60.000-260.000 (135.000) for 100SP; 30.000 (15.000) for 40FF60SP; and 105.000-135.000 (120.000) for 40FF60DP. Concentration of DHA, EPA, and ARA was the highest at broodstock fed with 4OFF60DP compared to the other 2 diets. Based on the naturally gonad development at the prematuration stage, shrimps which were fed with 4OFF6ODP gave better performaces and at the maturation stage, combination of 4OFF60DP diet gave relatively similar reproductive performances to shrimp fed with 10OFF and it was better compared to 40FF60SP

\section{KEYWORDS: maturation, semi-moist pelet, matured gonad}

\section{PENDAHULUAN}

Meskipun usaha budidaya udang windu sudah dilakukan dalam waktu yang cukup panjang, unit-unit perbenihannya masih menggunakan induk alam untuk produksi telur dan larva karena kualitas larva yang dihasilkan lebih baik dibandingkan induk yang diperoleh dari tambak. Akan tetapi, penangkapan induk udang windu secara terus-menerus akan menurunkan populasi induk udang windu di alam. Selain itu, induk yang diperoleh dari alam (laut dan samudera) umumnya terinfeksi penyakit virus yang dapat menyebabkan kematian massal benih udang di tambak setelah beberapa minggu penebaran (Flegel \& AldaySanz, 1998). Salah satu upaya yang telah dilakukan untuk mengatasi hal ini adalah mengembangkan teknik domestikasi induk SPF di tambak (Menasveta et al., 1993) maupun dalam wadah terkontrol (Coman et al., 2005).

Beberapa penelitian menunjukkan bahwa frekuensi kematangan gonad dan pemijahan induk udang windu dari alam lebih tinggi dibandingkan induk asal tambak (Menasveta et al., 1989), serta penurunan fekunditas telur dari setiap pemijahan signifikan terjadi pada induk asal tambak dibandingkan induk alam (Primavera \& Posadas, 1981). Rendahnya performansi reproduksi induk asal tambak diduga berhubungan dengan tidak lengkapnya komposisi nutrisi esensial dalam pakan yang diberikan selama masa perkembangan gonad (fase prematurasi dan maturasi) di tambak. Pe- nurunan kualitas telur dan larva yang terjadi pada induk alam terutama setelah pemijahan yang kedua kalinya juga diduga karena faktor nutrisi.

Keberhasilan pematangan gonad dan pemijahan di unit-unit perbenihan yang menggunakan induk alam disebabkan oleh terpenuhinya kebutuhan nutrisi esensial untuk proses reproduksi yang diperoleh selama induk hidup di alam. Selain itu, pakan yang diberikan selama proses maturasi masih berupa campuran pakan segar yang diperoleh dari laut seperti: cumi-cumi, cacing laut polychaeta, kerang-kerangan, krustase, dan ikan (Wouters et al., 2001 a). Banyak penelitian melaporkan bahwa penggunaan pakan segar tersebut sangat penting diduga karena kandungan nutrisinya berperan penting dalam proses reproduksi udang khususnya arachi-

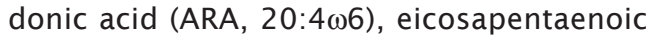
acid (EPA, 20:5 $\omega 3$ ), dan docosahexanoic acid (DHA, 22:6w3) (Cavalli et al., 1997; Coman et al., 2007a). Kendala utama penggunaan pakan segar tersebut adalah kandungan nutrisinya tidak konsisten dan dapat meningkatkan risiko transmisi penyakit bakteri dan virus khususnya jenis krustase dan cacing laut (Harrison, 1990).

Meskipun penggunaan pakan buatan memiliki banyak kelebihan khususnya untuk domestikasi udang windu secara indoor, performansi induk udang windu yang diberi pakan buatan belum sebaik induk yang diberi 
pakan segar. Sehingga unit perbenihan yang sudah memanfaatkan pakan buatan sebagian besar masih mengkombinasikan pakan pelet (pelet kering atau moist) dengan pakan segar dan dalam proporsi yang relatif rendah sekitar $16 \%$ dan selebihnya adalah campuran pakan segar (Wouters et al., 2000).

Dengan dikembangkannya proses domestikasi udang windu untuk mendapatkan larva SPF (specific pathogen free), penelitian tentang pakan induk semakin intensif dilakukan. Domestikasi udang windu yang saat ini dilakukan oleh beberapa negara masih menerapkan sistem yang berbeda. Program domestikasi dengan seluruh siklus hidup udang windu (dari telur hingga induk) dilakukan di dalam bak dengan sistem biosekuriti pertama kali dilakukan oleh CSIRO Australia pada tahun 1990-an (Coman et al., 2006; 2007b). Program domestikasi tersebut dilakukan dalam dua tahap pemeliharaan yaitu: delapan bulan pertama untuk fase pertumbuhan dan dari bulan 8 hingga bulan 11-12 untuk fase maturasi di mana pada fase ini udang sudah dapat digunakan sebagai induk untuk produksi telur. Pada fase pertumbuhan udang diberi pakan yang terdiri atas $20 \%$ cumi-cumi, $10 \%$ kerangkerangan dan $70 \%$ pakan pelet protein tinggi. Sementara selama fase maturasi, pakan udang terdiri atas 32,5\% cumi-cumi; 32,5\% kerangkerangan; $5 \%$ cacing polichaeta; dan $30 \%$ pelet maturasi (Comen et al., 2007a).

Percobaan ini bertujuan untuk mendapatkan formulasi pakan induk udang windu serta feeding regime-nya untuk fase prematurasi dan maturasi untuk mendukung usaha domestikasi udang windu baik di tambak maupun dalam wadah terkontrol. Sasaran penelitian ini adalah mengembangkan formulasi pakan yang sesuai untuk proses reproduksi induk udang windu.

\section{BAHAN DAN METODE}

\section{Pemeliharaan Udang Windu hingga Fase Prematurasi}

Untuk mendapatkan bobot udang yang diperlukan dalam kegiatan uji pakan, dilakukan pemeliharaan udang di tambak hingga bobot udang mencapai fase prematurasi atau bobot udang sekitar 60-70 g. Pemeliharaan udang ini dilakukan di Instalasi Tambak Maranak menggunakan petak tambak tanah. Udang yang ditebar adalah udang yang diperoleh dari tambak yang dipelihara dengan sistem intensif. Udang ditebar dalam tiga petakan berukuran $500 \mathrm{~m}^{2}$ dengan kepadatan 400 ekor/petak atau 0,8 ekor/ $\mathrm{m}^{2}$. Bobot awal rata-rata udang windu yang ditebar adalah 30 g. Selama masa pemeliharaan, udang diberi pakan komersil berprotein $40 \%$ yang diperkaya dengan vitamin $\mathrm{C}$ dan astaxanthin masingmasing sebanyak 0,05\%. Pakan diberikan tiga kali/hari sebanyak $5 \%$ dan diberikan selama 100 hari pemeliharaan. Sampling pertambahan bobot dilakukan setiap bulan, sedangkan pengukuran kualitas air dilakukan setiap hari, kecuali alkalinitas dilakukan sekali seminggu atau setelah aplikasi kapur.

Pada saat bobot udang rata-rata mencapai $70 \mathrm{~g}$, udang ditransfer dari tambak ke bak pemeliharaan di Instalasi Perbenihan Barru, Sulawesi Selatan. Setelah adaptasi selama seminggu dalam bak, udang selanjutnya disortir berdasarkan bobotnya untuk digunakan dalam kegiatan uji pakan. Berdasarkan hasil sortiran bobot udang yang ditransfer dari tambak, kegiatan uji pakan dilakukan dalam dua unit yaitu uji pakan untuk fase prematurasi dan fase maturasi.

\section{Uji Pakan Fase Prematurasi Udang Windu}

Unit percobaan 1 ini dirancang dengan rancangan acak lengkap (RAL) dengan tiga perlakuan dan dua ulangan. Perlakuan yang dicobakan adalah: 1) 100\% pakan induk komersil (100SP); 2) 40\% pakan segar dan 60\% pakan induk komersil bentuk semi-moist pelet (40FF60SP); dan 3) 40\% pakan segar dan 60\% pakan uji bentuk pelet kering (40FF60DP). Formulasi pelet kering uji disusun berdasarkan hasil-hasil penelitian yang sudah ada mengenai kebutuhan nutrisi induk udang windu untuk proses pematangan gonad (Hoa, 2009; Marsden et al., 1997; Paibulkichakul et al., 2008; Wouters et al., 2001 b). Formulasi dan estimasi komposisi nutrisi pakan uji disajikan pada Tabel 1. Profil asam lemak beberapa bahan baku pakan yang digunakan dalam pakan uji tertera pada Tabel 2. Pakan diberikan sebanyak empat kali sehari $(08.00 ; 12.00 ; 16.00$; dan 21.00). Pakan segar yang diberikan berupa cumi-cumi dan cacing laut (polychaeta) dengan proporsi 1:1.

Udang yang digunakan pada unit kegiatan ini adalah udang yang dikategorikan berada pada fase prematurasi yaitu yang bobotnya antara 55-80 g (Hoa et al., 2009; Paibulkichakul et al., 2008), sedangkan jantannya antara 4680 g. Padat tebar udang adalah 18 ekor/bak 
Tabel 1. Formulasi pakan uji (pelet kering) yang digunakan dalam fase prematurasi dan maturasi udang windu

Table 1. Formulation of experimental diet (dried pellet) used for pre-maturation and maturation stages of tiger shrimp

\begin{tabular}{lc}
\hline \multicolumn{1}{c}{ Bahan (Ingredient) } & g/kg \\
\hline Tepung ikan (Brown fishmeal) & 250 \\
Tepung rebon (Mysid meal) & 210 \\
Tepung kerang (Oyster meal) & 200 \\
Gluten gandum (Wheat gluten) & 30 \\
Dedak halus (Rice bran) & 30.15 \\
Terigu (Wheat flour) & 125 \\
Minyak ikan (Fish oil) & 45 \\
Lesitin kedelai (Soy lecithi) 70\% & 15 \\
Kolesterol (Cholesterol) & 2 \\
Campuran vitamin & 35 \\
Vitamin premix & \\
Campuran mineral & 30 \\
Mineral premix & 1 \\
Stay C & \\
Carophyll pink & 0.4 \\
Vitamin A dan (and) D & 0.2 \\
Vitamin E & 25 \\
CMC & \\
\hline
\end{tabular}

dengan rasio antara jantan dan betina adalah $1: 1$. Wadah yang digunakan adalah enam bak beton masing-masing berukuran $1,8 \mathrm{~m}^{2}$ (volume $3 \mathrm{~m}^{3}$ ) yang berada di luar ruangan. Air disuplai dengan sistem air mengalir (flow through). Pengukuran kualitas air dilakukan setiap hari kecuali alkalinitas dilakukan sekali dua minggu. Setelah dua bulan pemberian pakan uji, udang yang telah mencapai bobot sekitar $80 \mathrm{~g}$ diablasi sebanyak dua ekor/bak untuk diamati proses reproduksinya.

\section{Uji Pakan Fase Maturasi Udang Windu}

Unit percobaan 2 ini juga dirancang dengan rancangan acak lengkap (RAL) dengan tiga perlakuan dan dua ulangan. Perlakuan yang dicobakan adalah: 1) 100\% pakan segar (100FF); 2) 40\% pakan segar dan 60\% pakan induk komersil bentuk semi-moist pelet (40FF60SP); dan 3) 40\% pakan segar dan 60\% pakan uji bentuk pelet kering (40FF60DP). Pelet kering uji yang digunakan dalam percobaan ini sama dengan yang digunakan pada percobaan unit 1. Pakan uji diberikan sebanyak $2,5 \%$ dari biomassa dengan frekuensi pemberiannya sebanyak empat kali sehari yang waktu pemberiannya sama dengan percobaan unit 1 yaitu $08.00 ; 12.00 ; 16.00$; dan 21.00 .

Udang yang ditebar bobotnya antara 83$111 \mathrm{~g}$ untuk betina yang dikategorikan dalam fase maturasi, sedangkan bobot jantannya antara 45-86 g. Jumlah udang yang ditebar

Tabel 2. Profil asam lemak beberapa bahan baku yang digunakan dalam formulasi pakan uji dan sebagai pakan segar

Table 2. Fatty acids profile of several ingredients used in formulation of experimental diet and as fresh feed

\begin{tabular}{|c|c|c|c|c|c|}
\hline $\begin{array}{l}\text { Nutrien } \\
\text { Nut rient }\end{array}$ & $\begin{array}{l}\text { Rebon } \\
\text { Mysid }\end{array}$ & $\begin{array}{l}\text { Cumi-cumi } \\
\text { Squid }\end{array}$ & $\begin{array}{l}\text { Cacing laut } \\
\text { Seaworm }\end{array}$ & $\begin{array}{l}\text { Tiram } \\
\text { Oyster }\end{array}$ & $\begin{array}{c}\text { Tepung } \\
\text { ikan impor } \\
\text { Imported } \\
\text { fishmeal }\end{array}$ \\
\hline Kadar le mak (Fat content) (\%) & 2.61 & 7.54 & 7.22 & 9.36 & 12.05 \\
\hline $\begin{array}{l}\text { Jenis a sam lemak } \\
\text { Type of fatty acid }\end{array}$ & $\begin{array}{l}\text { \% dalam } \\
\text { lemak } \\
\% \text { in fat }\end{array}$ & $\begin{array}{l}\% \text { dalam } \\
\text { lemak } \\
\% \text { in fat }\end{array}$ & $\begin{array}{l}\% \text { dalam } \\
\text { lemak } \\
\% \text { in fat }\end{array}$ & $\begin{array}{c}\text { \% dalam } \\
\text { lemak } \\
\% \text { in fat }\end{array}$ & $\begin{array}{l}\% \text { dalam } \\
\text { lemak } \\
\% \text { in fat }\end{array}$ \\
\hline Linoleic acid, C18:2n6 & 1.59 & 6.87 & 1.28 & 1.08 & 0.86 \\
\hline Linolenic acid, C18:3n3 & 1.37 & 2.52 & 0.74 & 0.14 & 0.48 \\
\hline Arachidonic acid,C20:4n6 & 3.57 & 0.62 & 2.82 & 1.97 & 0.77 \\
\hline Eic osapentaenoic acid, C20:5n3 & 8.81 & 8.44 & 1.61 & 5.45 & 6.08 \\
\hline Docosahexaenoic acid, C22:6n 3 & 14.85 & 12.67 & 0.14 & 9.73 & 16.31 \\
\hline
\end{tabular}


adalah 9 ekor/bak dengan rasio betina : jantan 1:3. Intensitas cahaya dalam ruangan dikurangi selama pemeliharaan untuk mendukung proses perkawinan secara alami. Pemeliharaan dilakukan hingga performansi reproduksi dapat diamati.

Parameter biologis yang diamati adalah pertambahan bobot, sintasan, serta performansi reproduksi yang meliputi tingkat kematangan gonad betina sebelum dan setelah ablasi, persentase pemijahan, dan fekunditas telur. Proksimat analisis untuk beberapa sampel yang meliputi bahan pakan, pakan uji, dan karkas udang windu dilakukan dengan metode AOAC International (1999), sedangkan analisis asam lemak dilakukan dengan menggunakan Gas Chromatography (Christie, 1989). Data yang diperoleh akan dianalisis dengan menggunakan software SPSS versi 15.

\section{HASIL DAN BAHASAN}

\section{Profil Asam Lemak Beberapa Bahan Baku Pakan dan Pakan Uji}

Profil asam lemak dari beberapa bahan baku yang digunakan dalam formulasi pakan pada Tabel 2 memperlihatkan cumi-cumi, tiram, dan tepung ikan mengandung EPA dan DHA yang relatif tinggi dibandingkan rebon dan cacing laut. Akan tetapi kandungan ARA tertinggi di antara bahan yang dianalisis adalah dalam tepung cacing laut yaitu 2,82\% (dari lemak) atau 0,20\% (dari bahan).

Komposisi nutrien dua pakan uji yang digunakan pada uji pakan fase maturasi disajikan pada Tabel 3. Dari hasil analisis kimia yang dilakukan, kadar protein pakan pelet uji relatif sama dengan yang diestimasi sekitar $45 \%$ dan lebih rendah dibandingkan kadar protein pakan induk komersil yaitu sekitar $50 \%$. Kadar serat kasar pakan pelet uji lebih tinggi dibandingkan dengan pakan induk komersil masing-masing $10 \%$ dan $5 \%$.

Berdasarkan hasil analisis, profil asam lemak kedua pakan tersebut relatif sama, meskipun kadar asam linoleat (LOA) pakan pelet uji lebih rendah dibandingkan pakan komersil $(0,55 \%$ dan 0,49\%). Sebaliknya, kadar DHA pakan pelet uji relatif lebih tinggi dari pakan induk komersil masing-masing 1,38\% dan 1,29\%. Karena analisis mikronutrien yang dilakukan terbatas hanya pada profil asam lemak, maka informasi yang lebih detil mengenai perbedaan kadar mikro nutrien dari kedua pakan uji tersebut tidak didapatkan.

\section{Pertumbuhan Udang Windu di Tambak}

Sintasan udang windu selama 100 hari pemeliharaan di tambak adalah 30\%, sementara pertambahan bobotnya sebesar $95 \%$. Pertumbuhan udang windu selama pemeliharaan tersebut disajikan pada Gambar 1. Pada Gambar 1 terlihat bahwa pertumbuhan udang windu setelah berumur 220 hari (sekitar 7,3 bulan) masih menunjukkan pertumbuhan yang linier. Menurut Rothlisberg (1998), pertumbuhan udang penaeid di alam sangat cepat pada enam hingga sembilan bulan pertama sejak menetas dan selanjutnya mencapai fase yang stagnan.

Pemberian pakan udang komersil dengan protein sekitar $40 \%$ yang diperkaya dengan vitamin $\mathrm{C}$ dan astaxanthin dengan frekuensi pemberiannya sebanyak tiga kali/hari selama pemeliharaan diduga memenuhi kebutuhan nutrisi udang untuk tumbuh optimal. Meskipun informasi mengenai pertumbuhan udang windu hingga fase pertumbuhan akhir di tambak masih sangat terbatas, Paibulkichakul et al. (2008) melaporkan bahwa udang windu betina yang dipelihara di tambak komersil selama enam bulan memiliki bobot antara 48$50 \mathrm{~g}$, sedangkan yang jantan bobotnya sekitar 35-38 g. Sementara menurut Coman et al. (2005), udang windu yang dipelihara dalam bak selama delapan bulan pertambahan bobotnya mencapai $200 \%$ jika diberi kombinasi pakan antara pelet berprotein tinggi sebanyak $70 \%$ dan 30\% pakan segar dibandingkan jika udang diberi pakan hanya sekali dalam sehari dengan komposisi pakan yang sedikit berbeda yaitu $60 \%$ pakan komersil dan $40 \%$ pakan segar. Meskipun sistem pemeliharaannya berbeda, tingginya pertambahan bobot udang yang diberi kombinasi pakan menunjukkan bahwa pada fase pertumbuhan akhir, udang yang dipelihara di bak membutuhkan pakan segar dalam proporsi tertentu.

\section{Sintasan dan Tingkat Kematangan Gonad Udang Windu Fase Prematurasi}

Sintasan udang windu menunjukkan penurunan yang signifikan, terutama pada masa pemeliharaan 90 hari (Gambar 2). Pada Gambar 2 terlihat bahwa pada 30 hari pertama pemeliharaan udang di bak, kematian udang sudah terjadi pada ketiga perlakuan di mana 
Tabel 3. Komposisi nutrien pakan pelet dan pakan induk komersil yang digunakan dalam uji pakan (\%)

Table 3. Nutrient composition of the dried pellet and semi-moist diet used in the feeding trial (\%)

\begin{tabular}{|c|c|c|}
\hline $\begin{array}{l}\text { Nut rien } \\
\text { Nut rient }\end{array}$ & $\begin{array}{l}\text { Pakan pelet uji } \\
\text { Tested pellet }\end{array}$ & $\begin{array}{c}\text { Pakan induk komersil } \\
\text { Commercial maturation diet }\end{array}$ \\
\hline Bahan kering (Dry matter) & 91.9 & 89.9 \\
\hline Prote in kasar (Crude protein) & 45.1 & 50.5 \\
\hline Le mak (Lipid) & 9.0 & 8.9 \\
\hline Abu (Ash) & 10.3 & 8.4 \\
\hline Serat kasar (Crude fibre) & 10.6 & 5.1 \\
\hline Energi (Energy) $(\mathrm{GE}, \mathrm{MJ} / \mathrm{kg})^{*}$ & 17.5 & 16.6 \\
\hline LOA $(18: 2 n-6)$ & 0.49 & 0.55 \\
\hline LNA $(18: 3 n-3)$ & 0.05 & 0.08 \\
\hline ARA $(20: 4 n-6)$ & 0.29 & 0.32 \\
\hline $\operatorname{EPA}(20: 5 n-3)$ & 1.08 & 1.29 \\
\hline DHA $(22: 6 n-3)$ & 1.38 & 1.29 \\
\hline Fosfolipid (Phospholipid) ${ }^{*}$ & 2.82 & $T^{* \ldots *}$ \\
\hline Kolesterol (Cholesterol)* & 0.31 & TD \\
\hline Vitamin $C^{*}$ & 0.2 & TD \\
\hline Vitamin $E^{*}(\mathrm{mg} / \mathrm{kg})$ & 100 & TD \\
\hline Astaxanthin* (mg/kg) & 106 & TD \\
\hline
\end{tabular}

Keterangan (Note):

Nilai diestimasi berdasarkan kadar nutrien dari setiap bahan pakan dengan menggunakan formulator pakan (Values were estimated by nutrient content of each ingredient used database in a feed formulator)

** Data tidak ada/tidak dianalisis (Data are unavailable/not analized)

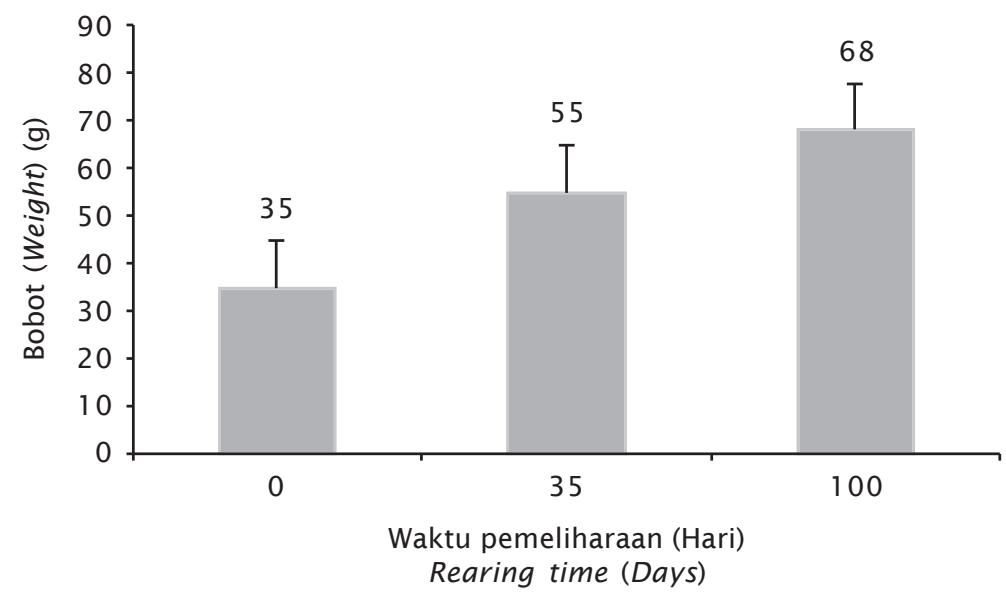

Gambar 1. Pertumbuhan udang windu selama pemeliharaan di tambak ( \pm SD, 2 ulangan)

Figure 1. Growth of pond reared tiger shrimp during research $( \pm S D$, duplicates) 


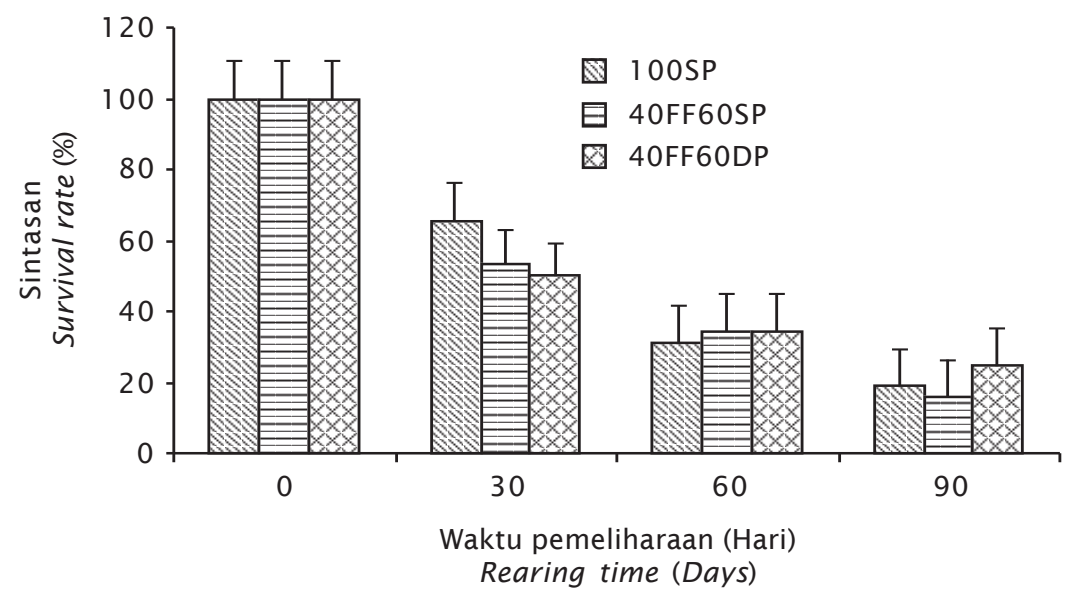

Gambar 2. Sintasan udang windu asal tambak fase prematurasi yang diberi kombinasi pakan yang berbeda

Figure 2. Survival rate of pond reared tiger shrimp at prematuration stages fed different combinations of maturation diet

terendah terjadi pada udang yang diberi pakan 100SP dan terendah pada 40FF60DP. Akan tetapi pada hari ke-90, sintasan tertinggi diperoleh pada udang yang diberi pakan 40FF60DP yaitu sebesar 25\%. Meskipun tidak berbeda nyata dengan udang yang diberi pakan 100SP yaitu $18,8 \%$; perubahan pola sintasan tersebut menunjukkan adanya masa transisi dari preferensi udang terhadap jenis pakan yang selanjutnya memengaruhi sintasan udang. Selama masa pemeliharaan di tambak, udang diberi pakan hanya pakan buatan, sehingga diawal pemeliharaan dalam bak, diduga udang lebih banyak mengkonsumsi pakan buatan dibanding pakan segar. Sementara itu, udang yang diberi pakan 40FF60SP memiliki sintasan terendah yaitu $15,7 \%$ dan berbeda nyata dengan sintasan udang yang diberi dua jenis pakan lainnya.

Berdasarkan pengamatan yang dilakukan, udang yang mengalami kematian pada umumnya mengalami gagal moulting berupa pergantian karapas yang terjadi tidak sempurna dan karapas udang tidak mengalami pengerasan. Gagal moulting tersebut diduga berhubungan erat dengan kondisi kualitas air selama pemeliharaan khususnya alkalinitas yang berkisar antara 74,2-84,8 mg/L. Kisaran tersebut relatif rendah jika dibandingkan dengan kisaran yang perlu dipertahankan selama pemeliharaan berlangsung yaitu 80-140 mg/L (Coman et al., 2005). Alkalinitas berfungsi sebagai buffer atau penyangga $\mathrm{pH}$, sangat penting terutama untuk menahan naik-turunnya dan goncangan $\mathrm{pH}$. Udang mengalami kesulitan moulting jika alkalinitas di bawah $75 \mathrm{mg} / \mathrm{L}$ dan pengerasan cangkang pasca moulting terhambat pada $\mathrm{pH}$ rendah. Selama pemeliharaan berlangsung, peningkatan konsentrasi alkalinitas tidak dilakukan sehingga sintasan yang relatif rendah yang terjadi pada percobaan ini diduga karena rendahnya alkalinitas. Menurut Coman et al. (2005), untuk meningkatkan alkalinitas air selama pemeliharaan udang di dalam bak dapat dilakukan dengan menambahan sodium bikarbonat secara berkala.

Dari dua udang betina yang diablasi dari setiap perlakuan, ternyata udang yang diberi pakan 100SP dan 40FF60DP ditemukan matang gonad hingga TKG III masing-masing satu ekor pada satu ulangan (rata-rata 0,5 ekor) seperti yang tercantum pada Tabel 4 . Bobot udang betina tersebut adalah $91 \mathrm{~g}$ (100SP) dan $104 \mathrm{~g}$ (40FF60DP) dengan umur sekitar sebelas bulan. Tingkat kematangan gonad kedua udang tersebut tidak berkembang hingga memijah diduga karena faktor lingkungan yang tidak mendukung karena bak terletak di luar ruangan.

\section{Performansi Reproduksi Udang Windu Fase Maturasi}

Performansi reproduksi udang windu fase maturasi dapat dilihat pada Tabel 5. Setelah 12 hari pemberian pakan perlakuan, ditemu- 
Tabel 4. Bobot udang windu asal tambak fase prematurasi yang diablasi dan jumlah serta umur udang windu yang matang gonad

Table 4. Weight of pond reared shrimp phase prematuration at ablation and number and age of matured shrimp after ablation

\begin{tabular}{|c|c|c|c|}
\hline $\begin{array}{l}\text { Paramet er reproduksi } \\
\text { Reproduct ive traits }\end{array}$ & $100 \mathrm{SP}$ & 40FF60SP & 40FF60DP \\
\hline $\begin{array}{l}\text { Bobot udang windu saat diablasi } \\
\text { Weight of ablated shrimp (g) }\end{array}$ & $82-91$ & $88-99$ & 79-104 \\
\hline $\begin{array}{l}\text { Jumlah udang windu betina yang matang } \\
\text { gonad (TKG III) (e kor) (Number of female } \\
\text { maturing to ovary stage III (ind.)) }\end{array}$ & 0.5 & 0 & 0.5 \\
\hline $\begin{array}{l}\text { Bobot (g) dan umur (hari) udang windu } \\
\text { yang matang gonad (Weight }(\mathrm{g}) \text { and age } \\
\text { (days) of matured female) }\end{array}$ & $\begin{array}{c}91 \text { dan (and) } \\
326 \text { (11 bulan) } \\
(11 \text { months })\end{array}$ & $\begin{array}{l}\text { Tidak ada } \\
\text { None }\end{array}$ & $\begin{array}{c}104 \text { dan (and) } \\
326 \text { (11 bulan) } \\
(11 \text { months })\end{array}$ \\
\hline
\end{tabular}

Tabel 5. Performansi reproduksi udang windu asal tambak fase maturasi yang diberi kombinasi pakan yang berbeda ( \pm SD, 2 ulangan)

Table 5. Reproductive performance of pond reared shrimp at maturation phase fed different combinations of maturation diet $( \pm \mathrm{SD}$, duplicates)

\begin{tabular}{lccc}
\hline \multicolumn{1}{c}{$\begin{array}{c}\text { Paramet er reproduksi } \\
\text { Reproduct ive traits }\end{array}$} & 100FF & 40FF6OSP & 40FF60DP \\
\hline $\begin{array}{l}\text { Bobot awal udang windu betina } \\
\text { Initial ind. female weight (g) }\end{array}$ & $\begin{array}{c}98 \pm 8.9 \\
(\mathrm{n}=5)\end{array}$ & $\begin{array}{c}97.8 \pm 6.8 \\
(\mathrm{n}=5)\end{array}$ & $\begin{array}{c}96.7 \pm 8.1 \\
(\mathrm{n}=5)\end{array}$ \\
$\begin{array}{l}\text { Bobot awal udang windu jantan } \\
\text { Initial ind. male weight (g) }\end{array}$ & $\begin{array}{c}65.5 \pm 7.5 \\
(\mathrm{n}=4)\end{array}$ & $\begin{array}{c}64.8 \pm 6.1 \\
(\mathrm{n}=4)\end{array}$ & $\begin{array}{c}61.9 \pm 8.1 \\
(\mathrm{n}=4)\end{array}$ \\
$\begin{array}{l}\text { Jumlah udang matang gonad alami } \\
\text { Number of naturally matured stock }\end{array}$ & $1(\mathrm{n}=5)$ & $0(\mathrm{n}=5)$ & $1.0(\mathrm{n}=5)$ \\
$\begin{array}{l}\text { Jumlah udang memijah alami } \\
\text { Number of stock naturally spawning }\end{array}$ & $0.5(\mathrm{n}=5)$ & $0(\mathrm{n}=5)$ & $0.5(\mathrm{n}=5)$ \\
$\begin{array}{l}\text { Jumlah udang matang gonad setelah ablasi (ekor) } \\
\text { Number of stock maturing after ablation (ind.) }\end{array}$ & $1.5(\mathrm{n}=4)$ & $0.5(\mathrm{n}=5)$ & $1.0(\mathrm{n}=5)$ \\
$\begin{array}{l}\text { Kisaran bobot udang windu saat ablasi } \\
\text { Range of stock weight at ablation (g) }\end{array}$ & $95-111$ & $92-110$ & $90-108$ \\
$\begin{array}{l}\text { Jumlah udang memijah setelah ablasi } \\
\text { Number of stock spawning per ablated stock }\end{array}$ & $1.0(\mathrm{n}=4)$ & $0.5(\mathrm{n}=4)$ & $1.0(\mathrm{n}=4)$ \\
$\begin{array}{l}\text { Kisaran dan rata-rata fekunditas telur (butir/induk) } \\
\text { Number of spawned egg (pcs/ind.) }\end{array}$ & $60,000-260,000$ & 30,000 & $105,000-135,000$ \\
\hline
\end{tabular}

kan satu ekor udang betina yang matang gonad secara alami yaitu udang yang diberikan 40FF60DP pada salah satu ulangannya dan seminggu kemudian diamati lagi satu ekor yang matang gonad pada pelakuan 100FF juga pada salah satu ulangan. Hingga percobaan berakhir, total udang yang matang gonad pada dua perlakuan tersebut masing-masing sebanyak dua ekor. Jumlah udang betina yang matang gonad mengalami peningkatan setelah ablasi dan ditemukan pada semua perlakuan. Semua udang yang matang gonad tersebut dapat memijah dengan kisaran fekunditas telur yang beragam. Udang yang diberikan pakan 
100FF mempunyai rata-rata fekunditas telur sebesar 135.000 butir, sedangkan udang yang diberi pakan 40FF60DP fekunditas telurnya sebesar 120.000 butir. Pemberian pakan 40FF 60SP secara umum menghasilkan performansi yang lebih rendah dibandingkan dua pakan uji lainnya. Dari semua telur yang dipijahkan oleh udang betina selama masa pemberian pakan, semuanya tidak terbuahi diduga karena tidak terjadinya perkawinan secara alami sehingga telur tidak ada yang berkembang hingga menetas.

Dengan ditemukannya udang betina yang matang gonad secara alami pada dua jenis pakan uji menunjukkan bahwa pakan yang diberikan memberikan pengaruh yang baik terhadap perkembangan gonad udang betina, meskipun jumlahnya masih sangat terbatas. Coman et al. (2007b) melaporkan bahwa setelah pemberian dua jenis kombinasi pakan maturasi ditemukan hanya satu dari 17 ekor induk betina udang windu (F-2) dari satu ulangan (ulangan sebanyak tiga) yang bisa matang gonad secara alami yang diberi pakan kontrol yaitu kombinasi pakan yang terdiri atas 32,5\% cumi-cumi; 32,5\% kerang-kerangan; 5\% polychaetes (Marphysa sp.) dan 30\% pelet sejak udang berumur sepuluh bulan hingga pengamatan reproduksi dilakukan.

Fekunditas telur yang diperoleh pada percobaan ini secara umum masih relatif rendah, meskipun kisarannya termasuk dalam kisaran yang dihasilkan oleh beberapa penelitian yang telah dilakukan sebelumnya. Comen et al. (2005) melaporkan bahwa fekunditas telur dari beberapa famili udang windu yang dipelihara dalam bak terkontrol maupun raceway berkisar antara 56.260-167.710 butir/induk betina berumur antara 11-17 bulan. Udang-udang tersebut diberi pakan berupa kombinasi antara cumi-cumi 20\%, kerang 5\% dan pakan komersil berprotein tinggi $70 \%$ selama 8 bulan, dan fase selanjutnya dari 8 hingga 11 bulan udang diberi pakan berupa cumi-cumi 30\%, kerangkerangan $20 \%$, polychaetes $5 \%$ dikombinasikan dengan pelet $45 \%$.

Hasil penelitian domestikasi udang windu yang dilakukan oleh Hoa (2009) menunjukkan fekunditas telur yang juga bervariasi berkisar antara 60.000-617.000 butir telur/pemijahan tetapi rata-ratanya lebih tinggi yaitu 309.630 butir. Pakan maturasi yang diaplikasikan adalah pakan segar $40 \%$ yang terdiri atas cumi-cumi $37 \%$, tiram $27 \%$, cacing laut $17 \%$, hati babi $19 \%$ dikombinasikan dengan $60 \%$ pakan semi-moist pelet. Perbedaan fekunditas tersebut diduga karena diversitas pakan segar yang digunakan dalam percobaan mereka lebih tinggi dibandingkan hanya dua jenis pakan segar (cumicumi dan cacing laut) yang digunakan pada penelitian ini. Dari beberapa pakan alami yang banyak digunakan untuk maturasi, yang paling berperan dalam proses pematangan gonad dan pemijahan udang penaied adalah cumi-cumi dan cacing laut (Yano, 2000; Meunpol, 2005). Peran kedua jenis pakan alami tersebut dalam proses maturasi dan pemijahan belum dipahami sepenuhnya, tetapi beberapa penelitian melaporkan bahwa pakan alami tersebut kaya akan n-3 HUFA dan PUFA terutama EPA, DHA, dan ARA (Primavera, 1985; Wouters et al., 2001 a dan Racotta et al., 2003). Hasil analisis yang diperoleh pada penelitian ini menunjukkan bahwa cumi-cumi kaya akan EPA dan DHA dan cacing laut mengandung ARA yang tinggi. Cacing laut jenis polychaetes tidak hanya sebagai sumber HUFA dan ARA tetapi juga diduga mengandung komponen aktif yang berhubungan dengan hormon reproduksi (Lytle et al., 1990). Kandungan ARA dalam telur sangat berhubungan dengan fekunditas dan produksi telur udang windu asal tambak menunjukkan pentingnya peranan ARA tersedia dalam pakan maturasi.

Rendahnya perkawinan alami yang diperoleh pada beberapa penelitian domestikasi udang windu masih menjadi kendala dalam upaya komersialisasi induk udang ini. Dari 16 induk betina yang digunakan dalam satu ulangan pada percobaan yang dilakukan oleh Hoa (2009) yang bisa mengalami perkawinan secara alami hanyalah berkisar $17 \%-22 \%$, masih relatif tinggi dibandingkan yang dilaporkan oleh team domestikasi CSIRO (Coman et al., 2005) dan pada penelitian ini. Sehingga upaya perkawinan secara buatan atau inseminasi sangat perlu dilakukan untuk mendapatkan telur yang fertil.

Komposisi proksimat dan profil asam lemak karkas induk udang windu setelah uji pakan ditampilkan pada Tabel 6 dan 7. Dari Tabel 6 dapat diketahui bahwa perbedaan pakan maupun kombinasinya tidak memengaruhi komposisi proksimat induk udang windu. Akan tetapi perbedaan kombinasi pakan berpengaruh signifikan pada beberapa jenis asam lemak dalam karkas. Kandungan EPA, DHA, dan ARA signifikan lebih tinggi pada induk yang diberi 40FF60DP dibandingkan dua pakan lainnya. Hal ini diduga karena pakan 40FF60SP adalah 
Tabel 6. Komposisi proksimat karkas udang windu asal tambak fase maturasi yang diberi kombinasi pakan yang berbeda ( \pm SD, 2 ulangan)

Table 6. Proximates composition of carcass of pond reared shrimp at maturation phase fed different combinations of maturation diet ( $\pm S D$, duplicates)

\begin{tabular}{lccc}
\hline $\begin{array}{c}\text { Komposisi proksimat } \\
\text { Proximate composition }\end{array}$ & 100 FF & 40FF60SP & 40FF60DP \\
\hline Kadar air (Moisture) & $7.4 \pm 1.6$ & $6.6 \pm 0.9$ & $6.5 \pm 0.4$ \\
Prote in kasar (Crude protein) & $58.3 \pm 2.1$ & $59.1 \pm 1.6$ & $58.7 \pm 0.9$ \\
Lemak (Lipid) & $1.6 \pm 0.7$ & $1.3 \pm 0.6$ & $2.4 \pm 1.8$ \\
Abu (Ash) & $13.6 \pm 0.5$ & $15.0 \pm 0.6$ & $13.0 \pm 0.5$ \\
Serat kasar (Crude fibre) & $15.2 \pm 0.6$ & $13.8 \pm 0.1$ & $15.5 \pm 0.1$ \\
BETN (NFE) & $11.4 \pm 0.3$ & $10.8 \pm 1.6$ & $10.6 \pm 3.2$ \\
\hline
\end{tabular}

Tabel 7. Profil asam lemak karkas udang windu asal tambak fase maturasi yang diberi kombinasi pakan yang berbeda (\% dari lemak \pm SD, 2 ulangan)

Table 7. Fatty acid profiles of carcass of pond reared shrimp at maturation phase fed different combinations of maturation diet (\% of lipid $\pm S D$, duplicates)

\begin{tabular}{lccc}
\multicolumn{1}{c}{$\begin{array}{c}\text { Asam lemak } \\
\text { Fatty acid }\end{array}$} & 100 FF & 40FF60SP & 40FF60DP \\
\hline Palmitic acid, C16:0 & $4.96^{\mathrm{a}} \pm 0.58$ & $4.00^{\mathrm{a}} \pm 0.37$ & $4.42^{\mathrm{a}} \pm 1.39$ \\
Stearic acid, C18:0 & $3.05^{\mathrm{a}} \pm 0.32$ & $3.15^{\mathrm{a}} \pm 0.35$ & $3.19^{\mathrm{a}} \pm 0.08$ \\
Oleic acid, C18:1n9 & $5.60^{\mathrm{a}} \pm 0.33$ & $5.76^{\mathrm{a}} \pm 0.21$ & $5.00^{\mathrm{a}} \pm 0.86$ \\
Linoleic acid, C18:2n6 & $2.21^{\mathrm{a}} \pm 0.01$ & $2.38^{\mathrm{a}} \pm 0.26$ & $3.02^{\mathrm{a}} \pm 1.41$ \\
Linolenic acid, C18:3n3 & $0.12^{\mathrm{a}} \pm 0.03$ & $0.13^{\mathrm{a}} \pm 0.01$ & $0.14^{\mathrm{a}} \pm 0.02$ \\
Arachidonic acid, C20:4n6 & $4.42^{\mathrm{a}} \pm 0.71$ & $4.71^{\mathrm{a}} \pm 0.05$ & $5.60^{\mathrm{b}} \pm 0.52$ \\
Eicosapentaenoic acid, C20:5n3 & $2.67^{\mathrm{a}} \pm 0.10$ & $2.82^{\mathrm{a}} \pm 0.67$ & $3.55^{\mathrm{b}} \pm 0.27$ \\
Docosahexaenoic acid, C22:6n3 & $3.25^{\mathrm{a}} \pm 0.17$ & $3.65^{\mathrm{a}} \pm 0.25$ & $5.17^{\mathrm{b}} \pm 0.95$ \\
\hline
\end{tabular}

kombinasi pakan segar dan pakan semi-moist pelet yang relatif lebih mudah buyar di dalam air dibandingkan pakan pelet. Dengan kata lain peluang terjadinya leaching nutrient khususnya mikronutrien lebih besar terjadi pada pakan semi-moist dibandingkan pakan pelet kering.

\section{KESIMPULAN}

Berdasarkan sintasan dan perkembangan gonad secara alami, udang windu yang diberi pakan 40FF60DP pada fase prematurasi memberikan performansi yang lebih baik. Udang pada fase maturasi yang diberi pakan yang sama yaitu 40FF60DP juga memberikan performansi reproduksi yang relatif sama dengan 100FF dan lebih baik dibandingkan pakan 40FF60SP.

\section{DAFTAR ACUAN}

AOAC International. 1999. Official Methods of Analysis, $16^{\text {th }}$ ed. Association of Official Analytical Chemists International, Gaithersberg, Maryland, USA, 1,141 pp.

Cavalli, R.O., Scardua, M.P., \& Wasielesky, W.J. 1997. Reproductive performance of different-sized wild and pond-reared Penaeus paulensis females. J. World Aquaculture Society, 28: 260-267.

Christie, W.W. 1989. Gas chromatography and lipids: A practical guide. The Oily press, UK, $416 \mathrm{pp}$.

Coman, G.J., Crocos, P.J., Arnold, S.J., Keys, S.J., Murphy, B., \& Preston, N.P. 2005. Growth, survival and reproductive performance of domesticated Australian stocks of the gi- 
ant tiger prawn, Penaeus monodon, reared in tanks and raceways. J. World of Aquaculture Soc., 36: 464-479.

Coman, G.J., Arnold, S.J., Peixoto, S., Crocos, P.J., Coman, F.E., \& Preston, N.P. 2006. Reproductive performance of reciprocally crossed wild-caught and tank reared Penaeus monodon broodstock. Aquaculture, 252: 372-384.

Coman, G.J., Arnold, S.J., Callaghan, T.R., \& Preston, N.P. 2007a. Effect of two maturation diet combinations on reproductive performance of domesticated Penaeus monodon. Aquaculture, 263: 75-83.

Coman, G.J., Arnold, S.J., Jones, M.J., \& Preston, N.P. 2007b. Effect of rearing density on growth, survival and reproductive performance of domesticated Penaeus monodon. Aquaculture, 264: 175-183.

Flegel, T.W. \& Alday-Sanz, V. 1998. The crisis in Asian shrimp aquaculture: Current status and future needs. J. Applied Ichthyology, 14: 269-273.

Harrison, K.E. 1990. The role of nutrition in maturation, reproduction and embryonic development of decapods crustaceans: a review. J. of Shellfish Res., 9: 1-28.

Hoa, N.D. 2009. Domestication of black tiger shrimp (Penaeus monodon) in recirculation systems in Vietnam. PhD thesis, Ghent University, Belgium, $189 \mathrm{pp}$.

Huang, J.H., Jiang, S.G., Lin, H.Z., Zhou, F.L., \& Ye, L. 2008. Effects of dietary highly unsaturated fatty acids and astaxanthin on the fecundity and lipid content of pondreared Penaeus monodon (Fabricus) broodstock. Aquaculture Research, 39: 240-251.

Lytle, J.S., Lytle, T.F., \& Ogle, J. 1990. Polyunsaturated fatty acid profiles as a comparative tool in assessing maturation diets of Penaeus setiferus. Aquaculture, 89: 287-299.

Marsden, G.E., McGuren, J.J., Hansford, S.W., \& Burke, M.J. 1997. A moist artificial diet for prawn broodstock: its effect on the variable reproductive performance of wild caught Penaeus monodon. Aquaculture, 149: 145-156.

Menasveta, P., Aranyakanonda, P., Rungsupa, S., \& Moree, N. 1989. Maturation and larviculture of penaeid prawns in closed recirculating seawater systems. Aquaculture Engineering, 8: 357-368.

Menasveta, P., Piyatiratitivorakul, S., Rungsupa, S., Moree, N., \& Fast, A.W. 1993. Gonad maturation and reproductive performance of giant tiger prawn (Penaeus monodon Fabricus) from the Andaman Sea and pond reared sources in Thailand. Aquaculture, 116: 191-198.

Meunpol, O., Duangjai, E., Yoopun, R., \& Piyatiratitivorakul, S. 2005. Determination of prostaglandin $\mathrm{E}_{2}\left(\mathrm{PGE}_{2}\right)$ in polychaetes (Perinereis sp.) and its effect on Penaues monodon oocytes development in vitro. In: Book of short communication, Larvi 2005. Ghent University, Belgium, p. 320-323.

Paibulkichakul, C., Piyatiratitivorakul, S., Sorgeloos, P., \& Menasveta, P. 2008. Improved maturation of pond-reared, black tiger shrimp (Penaeus monodon) using fish oil and astaxanthin feed supplements. Aquaculture, 282(1-4): 83-89.

Primavera, J.H. 1985. A review of maturation and reproduction in closed thelycum penaeids. In: Taki, Y., Primavera, J.H., Llobrera, J.A. (Eds.), Proceeding of the First International Conference on the Culture of Penaeid Prawn/Shrimp. Aquaculture Department, Southeast Asian Fisheries Development Center, Iloilo, Philippines, p. 47-63.

Primavera, J.H. \& Posadas, R.A. 1981. Studies on the egg quality of Penaeus monodon fabricus, based on morphology and hacthing rate. Aquaculture, 22: 269-277.

Racotta, I.S., Palacios, E., \& Ibarra, A.M. 2003. Shrimp larval quality in relation to broodstock condition. Aquaculture, 227: 107-130.

Rothlisberg, P.C. 1998. Aspects of penaeid biology and ecology of relevance to aquaculture: a review. Aquaculture, 164: 49-65.

Wouters, R., Nieto, J., \& Sorgeloos, P. 2000. Artificial diets for penaeid shrimp. Global Aquaculture Advocate, 3: 61-62.

Wouters, R., Lavens, P., Nieto, J., \& Sorgeloos, P. 2001 a. Penaeid shrimp broodstock nutrition: an updated review on research and development. Aquaculture, 202: 1-21.

Wouters, R., Piguave, X., Bastidas, L., \& Sorgeloos, P. 2001 b. Ovarian maturation and haemolymphatic vitellogenin concentration of Pacific white shrimp Litopenaeus vannamei (Boone) fed increasing levels of total dietary lipids and HUFA. Aquaculture Research, 32: 573-582.

Yano, I. 2000. Endocrine control of reproductive maturation in economically important crustacea for aquaculture. In: Adiyodi, K.G., Adiyodi, R.G. (Eds.), Reproductive Biology of Invertyebrate, vol. X. Wiley, New York, p. 161-194. 